\title{
УКРАЇНСЬКА ІСТОРИЧНА ЛЕКСИКОГРАФІЯ, ПИТАННЯ СПОЛУЧУВАНОСТІ І КОМБІНАТОРНИЙ СЛОВНИК УКРАЇНСЬКОЇ МОВИ
}

\author{
Ганна Дидик-Меуш \\ Інститут українознавства ім. І. Крип'якевича НАН України \\ ORCID: 0000-0001-7384-5782
}

\begin{abstract}
Анотація. У статті подано характеристику комбінаторного словника відповідно до засад практичної комбінаторної лексикографії, а також на тлі історичної лексикографії. Наведено основні принципи створюваного Комбінаторного словника української мови XVI-XVIII століть на основі ад'єктивно-субстантивних словосполучень, особливості його будови, специфіку джерельної бази, будову словникової статті. Згадано важливість короткого Словника малозрозумілих іменників, доданого до Комбінаторного словника української мови XVI-XVIII століть.
\end{abstract}

Ключові слова: сполучуваність, комбінаторика, історична лексикографія, комбінаторна лексикографія, історичний словник, комбінаторний словник, ад’єктивно-субстантивне словосполучення

Пропонований Комбінаторний словник украӥнської мови XVI-XVIII століть є історичним словником і водночас - комбінаторним, або словником сполучуваності ${ }^{1}$. Об'єктом його опису слугують ад'єктивно-субстантивні словосполучення, які вдалося виявити в українських різножанрових текстах XVI-XVIII ст.

\section{І. КОМБІНАТОРНІ СЛОВНИКИ ТА ЇХ ПРИЗНАЧЕННЯ}

У полі зору комбінаторної лексикографії перебувають теорія і практика укладання словників сполучуваності. До іiі базових понять належить поняття ,лінгвістична комбінаторика”, тобто вивчення комбінацій лексем, які виконують комунікативні завдання за необхідних умов їх реалізації і які можна скласти з певної кількості слів. Лінгвістична

Г. Дидик-Меуш, Комбінаторний словник української мови XVI-XVIII століть, [в:] Вона ж, Комбінаторика української мови XVI-XVIII ст.: теорія, практика, словник, Львів 2018, с. 503-687 (А-Б). 
комбінаторика досліджує „якісні та кількісні характеристики ізольованих елементів мови і цілих континуумів, до яких входять ці елементи впродовж встановленого періоду лінгвістичного часу"2. Завдяки цьому лінгвістам-лексикографам вдається виявити можливі чи неможливі умови поєднання елементів мови й отримати результати їхньої взаємодії. Комбінаторика присутня на кожному рівні мови і слугує основним принципом організації абсолютно всіх мовних одиниць, формою їх існування, еволюції та взаємодії. Визначальними для комбінаторики $є$ синтагматичні (лінійні), парадигматичні (нелінійні) та ієрархічні (родо-видові) відношення. Оскільки одним із видів відношень комбінаторики є синтагматичні відношення, можна кваліфікувати цю сферу прикладного мовознавства як комбінаторну лексикографію, маючи на увазі лексикографічну кодифікацію тільки синтагматичних відношень мовних одиниць.

Отже, термін комбінаторна лексикографія (або лексикографія сполучуваності) доволі точно відображає суть лексикографічного напрямку лінгвістичної комбінаторики. У сучасній практиці існує особливий тип словників, призначення яких - подати найбільш повний (порівняно 3 іншими словниками) обсяг відомостей про словосполучення, об'єднані асоціаціями довкола стрижневих слів ${ }^{3}$. Сучасна теорія лексикографії оперує різними класифікаціями словників, які свого часу запропонували Синді І. Лендау, Жан Маторе, Лев Щерба, Володимир Гак, Леонід Ступін, Петро Денисов, Валерій Морковкін, Анатолій Баранов, Ніна Лук'янова, Сергій Гриньов, Володимир Дубічинський, Марина Влавацька та ін. Проте не всі лексикографи виокремлюють тип КомС через відсутність єдиного трактування такого словника та його місця в системі словників. Традиційно КомС призначені для фіксації особливих, стійких словосполучень слів, які все частіше під впливом англійської мови називають колокаціями. Однак, як свідчить практика, сучасні КомС створені переважно за власною лексикографічною інтерпретацією їхніх авторів. Це, зокрема, стосується і лексикону Комбінаторний словник української мови XVI-XVIII століть, який створюється за оригінальною ідеєю та задумом.

\footnotetext{
2 М. Маковский, Лингвистическая комбинаторика: опыт типологической стратификации языковых структур, Москва 2006, с. 125.

3 М. Влавацкая, Комбинаторная лингвистика: аспекты изучения сочетаемости слов, Новосибирск 2016.
} 


\section{II. КОНЦЕПЦІЯ КОМБІНАТОРНОГО СЛОВНИКА УКРАЇНСЬКОЇ МОВИ ХVI-ХVIII СТОЛІТЬ}

Комбінаторний словник украӥнської мови XVI-XVIII століть - насамперед історичний словник, що виконує суто наукову функцію та загальнокультурну і має такі риси історичного словника: 1) документує мову тільки на основі доступних писемних пам'яток; 2) відображає тільки конкретне слововживання, можливо, часто оказіональне; 3) розглядає значення слова тільки в контексті; 4) відомості сучасної української мови використовує незначною мірою 4 . 3 огляду на сказане вище, історичний словник грунтується на таких трьох засадах: а) хронологічні рамки, б) джерельна база і в) склад (наповнення) словника.

Історики-лексикографи, намагаючись обійти труднощі під час укладання словникових статей, часто зводять словник до довідника, що є додатком до історичних текстів: а) до слова дають енциклопедичну довідку; б) застосовують принцип перекладного словника: ліворуч і праворуч співвідносять слова старої та нової епохи, між ними часто встановлюється начебто синонімічний зв'язок. Така практика, однак, створює ілюзію смислової тотожності, а насправді приховує те, що ці т.зв. „синоніми” вжиті в різних контекстах і мають різну сполучуваність. Тож створена завдяки таким перекладам „ілюзія змістової тотожності слів ховає реальні розходження їх використання: за загальною подібністю значень стоять справжні, хоча й не завжди очевидні відмінності в змістовому обсязі слова, які можна виявити в сукупності мовленнєвих контекстів”, „за цим криється й відмінність їх лексичної сполучуваності, різне місце цих т.зв. синонімів у синонімічних рядах" . Пропонований словник сполучуваності, укладений за текстами XVI-XVIII ст., допоможе виявити і лексикографічно впорядкувати таке розходження слів.

Окрім цього, Комбінаторний словник української мови XVI-XVIII століть - явище власне комбінаторної лексикографії, що $є$ самостійним напрямком у межах загальної теорії лексикографії. У сучасній лексикографічній практиці існує особливий тип словників, призначення яких - подати найбільш повний (порівняно з іншими словниками) обсяг відомостей про словосполучення, об'єднані асоціаціями довкола стрижневих слів. Порівняльний аналіз комбінаторних словників засвідчує низку способів фіксації сполучуваності слів, а також те, що вибір способу залежить від типу сполучуваності або від типу ілюстраційного значення в за-

4 Л. Гумецька, Історичний словник української мови (деякі аспекти теорії і практики укладання словника), „Мовознавство” 1967, № 1, с. 44-49.

5 Ю. Сорокин, Что такое исторический словарь?, [в:] Проблемы исторической лексикографии, Ленинград 1977, с. 18. 
гальних словниках. Автори комбінаторних словників демонструють сполучуваність відповідно до власного розуміння цього мовного явища і від мети його відображення. Через те в лінгвістиці існує різнобій у назвах (комбінаторний словник, тлумачно-комбінаторний словник, тлумачний словник сполучуваності, словник сполучуваності, словник валентності та дистрибуції, словник словосполучень, словник колокацій та ін. $\left.{ }^{6}\right)$, які 3 огляду на стрижневий термін кожної з них не можуть бути назвами-синонімами.

За призначенням комбінаторні словники поділяють на: а) системні (зокрема тезауруси) - лінгвоцентричні словники, призначені для спеціалістів-філологів із метою „відобразити зв'язки слова з усіма наявними в мові поширювачами"; б) ортологічні - антропоцентричні словники, призначені для носіїв мови, що активно послуговуються мовою у своїй професії (репортери, журналісти, письменники) з метою „зафіксувати найповніший перелік поширювачів кожного слова відповідно до мовної норми”; в) навчальні - „педагогічно орієнтовані словники”, які подають „тільки необхідні, з методичного погляду, слова разом із їхніми конкретними, найважливішими поширювачами"”. Увагу привертає перший тип - системний комбінаторний словник - лінгвоцентричний словник, адресований спеціалістам-філологам, призначення якого - відтворити зв'язки слова (у цьому випадку - ад'єктива) зі всіма наявними в українській мові XVI-XVIII ст. поширювачами (субстантивами). Марина Влавацька слушно зауважує, що „такого словника поки що не створено”. А це відкриває перспективу для лексикографічної роботи. До того ж, неусталеність вимог до комбінаторних словників та відсутність таких лексиконів дає укладачеві свободу вибору і щодо об’єкта та предмета опису, і щодо принципів.

Основні характеристики Комбінаторного словника української мови XVI-XVIII століть відповідають 7 базовим параметрам (або принципам) будь-якого комбінаторного словника: 1) мета і призначення; 2) характер відображення сполучуваності; 3) тип сполучуваності; 4) принцип опису сполучуваності; 5) характер розташування лексичних одиниць; 6) спосіб презентації лексичних значень; 7) джерельна база9.

Для підтвердження засад Комбінаторного словника української мови XVI-XVIII століть його авторка проаналізувала спосіб інтерпретації сполучуваності:

\footnotetext{
Г. Дидик-Меуш, Комбінаторика української мови XVI-XVIII ст...., с. 326-336.

М. Влавацкая, цит. праця, с. 51.

Там само.

Г. Дидик-Меуш, Комбінаторика української мови XVI-XVIII cm...., с. 326-336.
} 
а) в історичних словниках: Словарь малорусской старины Василя Ломиковського, Материаль для словаря письменной и книжной южнорусской речи $X V$-XVIII вв. Свгена Тимченка, Словник староукраӥнської мови $X I V-X V \mathrm{~cm}$. (гол. редкол. Лукія Гумецька), Словник украӥнської мови XVI-першої половини XVII cm. (відпов. ред.: Дмитро Гринчишин, Марія Чікало, Ганна Войтів), Українські краєвиди XVI-XVIII століть: слово, текст, словник (Ганна Дидик-Меуш та Олена Слободзяник);

б) у словничках-глосаріях: Словник застарілих слів і юридичних термінів (у кн.: Торгівля на Україні: Волинь і Наддіпрянщина. XIV-середина XVII століття), Словник застарілих слів, значень і юридичних термінів (у кн.: Документи Браилавського воєводства 1566-1606 років), Словник (у кн.: Ділова мова Волині і Наддніпрянщини ХVII ст.: Збірник актових документів), Словник застарілих слів і юридичних термінів (у кн.: Книга Київського підкоморського суду (1584-1644)), Словник застарілих, маловживаних та актових слів і виразів (у кн.: Львівський літопис і Острозький літописець. Джерелознавче дослідження), Словник малозрозумілих слів (у кн.: Лохвицька ратушна книга другої половини XVII ст.: Збірник актових документів), Словник застарілих та маловживаних слів (у кн.: Літопис Самовидия).

До сьогодні немає критеріїв розмежування словосполучень у межах одного класу, через те немає узгоджених принципів, прийомів та способів презентації ад'єктивно-субстантивних словосполучень (далі - АСС) у словниках. Хоч, як відомо, ад'єктивно-субстантивні словосполучення становлять особливий об'єкт лексикографії, який потребує:

а) чітких засад лексикографічного опису: вільне АCC - невільне АCC - АСС перехідного (проміжного) типу;

б) розмежування „лексичної” та „фразеологічної” частин словника, вивчення т.зв. „зони стійкості” словникової статті.

Огляд і аналіз поданих вище словникових матеріалів доводить таке: 1) АСС привертають пильну увагу укладачів; 2) відсутні єдині підходи теоретичного обгрунтування ступеня стійкості АCC і 3) через те відсутні єдині засади лексикографічного опису, а тому очевидним є різнобій у лексикографічній кодифікації. Більшість лексикографів керується власним досвідом та інтуїцією.

Тексти доступних пам'яток зумовили специфіку виявлення та добору АCС для Комбінаторного словника украйнської мови XVI-XVIII століть відповідно до таких основних принципів:

1. За структурою: а) просте АСC (80\%): зятєви сєнка <... по даного мъского тоє дворищє прода(л)я(м) єму $\left(\text { КСУМ }^{16-17}\right)^{10}$, Возмєщъ

10 Картотека Словника української мови XVI-першої половини XVII cm. Зберігається у відділі української мови Інституту українознавства ім. І. Крип'якевича НАНУ, м. Львів (далі - КСУМ ${ }^{16-17}$ ). 
собъ рђчи вонныхъ, <..> и кадила найсвђтльйщагw (серед. XVII ст. КСУМ ${ }^{16-17}$ ) та ін.;

б) ускладнене АCC (2 ACC в 1 ACC), у якому функцію стрижневого чи залежного атрибутивного компонента АCC виконує інше АСC, що не підлягає логічному поділу: поткали насъ люди великого князства (1546 КСУМ $\left.{ }^{16-17}\right)$, храма у(с)пєниє Пречистой Божсой Матєри (1600 КСУМ $^{16-17}$ ) та ін.

2. За розташуванням ад'єктива щодо субстантива: а) контактно у препозиції (30\%): за блг(с)вєнїємъ єго мл(с)ти прєподобньйшого о(т)ца Киръ Пєтра Могиль (1631 КСУМ $\left.{ }^{16-17}\right)$ та ін.; б) контактно в постпозиції (37\%): князь Кошєрскии, маршалок господскии, наславшы моџно// кгвалтомъ врядника своего перемишлского Юрка з многими людми поддаными (КСУМ ${ }^{16-17}$ ) та ін.; в) контактно у пре- та в постпозиції (10\%): [богъ] многоцђнными кроушъцами златими ${ }_{2}$, срьбръными сивъ зємлю] (Почаїв 1618 КСУМ $^{16-17}$ ) та ін.; г) дистантно (23\%): [nрємоудрый богъ] дрєва насади на нєй [на земли] различныи, плодоносныи (Почаїв, 1618 КСУМ $^{16-17}$ ) та ін.

3. За наявністю додаткових елементів АСС (слів-підсилювачів): [xc] з оусть єи [самаритянки] барзо солодкый мєд то $\epsilon(\mathrm{cm})$ похвалоу своєи славы выводи (m) (поч. ХVІІст. КСУМ ${ }^{16-17}$ ).

4. За наявності кількох ад'єктивів при одному субстантиві виокремлено стільки АСС, скільки ад'єктивів: отдаю зо всякими пожитками полными ${ }_{1}$ боровыми ${ }_{2}$, лесными ${ }_{3}$, и речными 4 (1559 КСУМ $\left.{ }^{16-17}\right)$ та ін.

Уведення АСС до тлумачних словників можна пояснити тим, що вони максимально наближені до слова згідно зі своєю функцією: АСС уживають як номінаційні одиниці. Це зумовлено вже самою граматичною природою сполучуваних слів, адже субстантив слугує іменем предметів-субстанцій, ад'єктиви ж називають їхні ознаки (постійні та змінні, зовнішні і внутрішні). А Комбінаторний словник украӥнської мови XVIXVIII століть - знаряддя для виконання поставленого завдання: максимально повно відтворити базу ад'єктивно-субстантивних словосполучень, виходячи від ад'єктива, що є реєстровим словом цього словника. Через те визначальним є врахування такого поняття, як „сполучуваність реєстрового ад'єктива" (тобто кількість інших елементів - субстантивів, 3 кожним із яких ад'єктив може вступати в певні відношення, наприклад, бути залежним від нього чи, навпаки, бути ним зумовленим, інакше кажучи - активна та пасивна сполучуваність відповідно активної і пасивної валентності): активна валентність стосується головного слова, пасивна - залежного. За різними концепціями теорії валентності використовують такі терміноназви: ичентрипетальна/ цеентрифугальна, ліва/ права ${ }^{11}$.

11 Г. Дидик-Меуш, Комбінаторика української мови XVI-XVIII cm...., с. 77-78. 
Варто, проте, запропонувати терміни відиентрова валентність (активна) і доцентрова валентність (пасивна). Активна валентність виникає тоді, коли вираз, що „заповнюе” валентність слова, синтаксично залежний від самого валентного слова (слово здатне приєднувати залежний елемент); пасивна валентність виникає тоді, коли вираз, що „заповнює” валентність слова, не підпорядковується йому, а навпаки, підпорядковує його собі. Це найчастіше характерне для словосполучень із ад'єктивованим дієприкметником, наприклад: виголена потилиия (Київ, 1621 КСУМ $\left.^{16-17}\right)^{12}$, де дієприкметник виголена має пасивну валентність стосовно субстантива потилица; так само і щодо словосполучення выданыи писма 'опубліковані послання' (противныи выданыи похотьлися указати писма - Київ, $1621 \mathrm{KCУM}^{16-17}$ ) та ін. Пасивна валентність характерна для таких частиномовних класів слів, як прикметник, прислівник, прийменник, сполучник, які, на відміну від актантів, $є$ сирконстантами (за Теньєром, початково сирконстанти - другорядні учасники ситуації).

У пропонованому дослідженні із комбінаторики української мови XVI-XVIII ст. (на матеріалі ад'єктивно-субстантивних словосполучень) валентність трактуємо як потенційну сполучуваність слова, що виявляється на рівні мови.

Комбінаторику української мови XVI-XVIII cm. можна вивчати тільки за наявності доступних текстів (свідчень тогочасного мовлення), через те домінантним є поняття „сполучуваність” - реалізація зв'язку одиниць мови на рівні мовлення і взагалі здатність слів сполучатися між собою; іншими словами, сполучуваність - це реалізована валентність на мовленнєвому рівні, тобто здатність слова поєднуватися в мовленні 3 певними словами для виконання того чи іншого змістового завдання або реалізації його валентності, іншими словами, сукупність словосполучень, у які входить чи може входити конкретне слово.

Для пропонованого словника особливо важливим є також визначення статусу ACC: 1) нестійкі неідіоматичні словосполучення; 2) стійкі неідіоматичні словосполучення і 3) словосполучення „малої” ідіоматичності; 4) ідіоми. Такі словосполучення належать до сфери лексичної сполучуваності.

Пропонований словник $є$ історичним, комбінаторним, тлумачним (частково - перекладним та енциклопедичним), за розміщенням лексичного матеріалу - прямим (алфавітним), за характером опису сполучуваності - лінгвоцентричним словником. Словник відображає лексико-синтаксичний i (частково) лексико-фразеологічний тип сполучуваності; до того ж лексичні одиниці, описані тут, мають різний ступінь стійкості та переосмислення: вільні АCC, АCС перехідного (проміжного) типу і фразео-

12 Картотека Словника української мови XVI-першої половини XVII cm. 
логічно зв'язані АСС. Лексикографічна інтерпретація АСС здійснюється на основі лінгвістичного, культурологічного і лексикографічного опису.

Концепція словника реалізована в його макроструктурі (передмова; список скорочень; словник; список джерел) і мікроструктурі (словникова стаття). Призначення словникової статті - подати якомога повнішу характеристику ад'єктива, зафіксувати різні види його оточення, контекстні та синтагматичні зв'язки, сигналізувати про сильні та слабкі зв'язки та, як зауважила Наталія Шведова, „помістити слово в його фразеологічне поле і показати різний ступінь фразеологічної зв'язності тих чи інших значень слова"13.

Словникова стаття має такі словникові зони:1) реєстрове слово; 2) варіанти реєстрового слова (якщо такі виявлені); 3) значення; 4) ілюстрація (АCC, реалізоване в мовленні XVI-XVIII ст. завдяки сполучувальній здатності субстантива й ад'єктива); 5) покликання на джерело із вказівкою на рік та місце його написання; 6) цитата-ілюстрація.

Нижче подамо розгорнуту характеристику будови словникової статті КомСУМ ${ }^{16-18}$ :

1. Реєстрове слово - ад'єктив (рідше - ад'єктивований дієприкметник) у найуживанішій фонетико-графічній формі.

2. Значення - тлумачення одно- чи багатозначного ад'єктива здійснене за допомогою сучасних літературних відповідників, за їх відсутності - описовим способом. Наприклад:

\section{адамантовый}

1.твердий, непохитний

• статечность адамантова [въ вђрђ отчистой] (Київ, 1621 КСУМ $\left.^{16-17}\right)^{14}$

2. беззаперечний, переконливий

- доводи адамантовыє [правды] (Київ, 1620-1621 КСУМ ${ }^{16-17}$ )

Або:

богоблагателный який містить чи виявляє благання до Бога

• книга богоблагательная [Леітургіаріонъ] (Львів, 1646 КСУМ $^{16-17}$ )

• офьри богоблагательныє (Львів, 1646 КСУМ $^{16-17}$ )

\section{благовђщенский (благовещенский)}

1. благовіщенський, названий на честь свята Благовіщення

- церковъ благовъщенска^ (Львів, 1626 КСУМ $\left.^{16-17}\right)^{15}$

2. благовіщенський, пов'язаний із церквою Благовіщення у м. Львові

13 Н. Шведова, Парадоксы словарной статьи, [в:] Национальная специфика языка и ее отражение в нормативном словаре, Москва 1988, с. 6.

14 Картотека Словника украӥнської мови XVI-першої половини XVII ст.

15 Там само. 
• попь благовъщенский (Львів, 1623 КСУМ $^{16-17}$ )

• наместникъ благовещенский (Львів, 1552 КСУМ $^{16-17}$ )

3. Основна частина - ексцерповані з текстів пам'ятки АСС, що є ілюстраційним підтвердженням досліджуваної сполучуваності, подані за такими принципами:

3.1. Кожне АСС уведене до словника зі спеціальним значком •

3.2. Субстантиви (незалежно від пре- чи постпозиції ад'єктивів у тексті пам'ятки) подано за абеткою послідовно у препозиції, ад'єктиви - послідовно в постпозиції, що зумовлено:

a) вимогою словника (стрункість і чіткість словникової статті);

б) вимогою потенційного користувача (зручність у користуванні і дохідливість у прочитанні);

в) вимогою автора словника (максимально відобразити історико-культурну панораму XVI-XVIII ст.). Наприклад:

аксамитный (оксамитный) оксамитний, оксамитовий

- апараты аксамитныє

- балдахіумъ аксамитноє <чорноє>

- брама оксамитная

- дылья оксамитная <чирвоная>

- єпетрахиль аксамитный

- жепанъ аксамитный <чирвоный>

- колдра аксамитная

• колпакъ оксамитный

- кунтушъ аксамитный

- летникъ аксамитный

- лиштва аксамитная <червона>

- мешокъ аксамитный

- окладъ аксамитный

• пасаманъ оксамитный

- петрахиль аксамитный

- покритя оксамитныє

- поясъ оксамитный

- саянъ оксамитный

- ферезия аксамитная

- чамара аксамитная

- шапка оксамитная

- шапочка оксамитная

- шаты аксамитныє

- шуба оксамитная 
3.3. Для повного відтворення означуваної реалії в ілюстрації наведено:

3.3.1. усі ад'єктиви-атрибутиви, виявлені при субстантиві (вони у спеціальних дужках $>$ ):

безсмертный (безсмертенъ) безсмертний, вічний

- ангелове безсмертны

- Богъ безсмертный <невидимый, самовластный, въчный, словесный, разумный>

- душа безсмертная <наша невидимая, въчная>

- женихъ безсмертный <небесный> образн. [Христосъ]

- правда безсмертная <царствующая и вьчная>

- существо безсмертноє $<$ подобноє ангелу $>$

3.3.2. предикативну основу чи іншу додаткову інформацію (вона у спеціальних дужках []):

безначалный (безначалній, безначальный) безначальний, споконвічний

- Богъ безначальный

• отецъ безначальный [Богъ]

• персони безначальнїи [Троицы]

- Сынъ безначалный

- Тройца безначальная

Або:

благопослушный послушний Богові, вірний, відданий

- желатели благопослушныє <и верныє>

- люди благопослушныє [церкви восточной]

• сыни благопослушныє [церковный клиръ]

3.4. Особливе призначення КомСУМ ${ }^{16-18}$ - інтерпретувати АCС перехідного типу. Ад'єктив, який входить до складу такого словосполучення, має, окрім тлумачення, спеціальну ремарку, яка вказує на особливий статус АСС та його зв'язок із позначуваною галуззю. Наприклад:

алоссовый алоевий (у складі ботанічної назви)

- древо алоєсовоє (XVIII ст. КТ) $)^{16}$

аметистовъ аметистовий (у складі мінералогічної назви)

- камень аметистовъ (XVI ст. КСУМ $\left.{ }^{16-17}\right)^{17}$

антимисный антимісний (у складі релігійної назви)

• губа антимисная (XVIII ст. КT)

\footnotetext{
16 Картотека Історичного словника украӥнського язика, за ред. Свгена Тимченка. Зберігається у відділі української мови Інституту українознавства ім. І. Крип'якевича НАНУ, м. Львів (далі - КТ).

17 Картотека Словника української мови XVI-першої половини XVII cm.
} 
антоновъ Антоніїв, пов'язаний зі св. Антонієм (у складі медичної назви)

• огонь антоновъ [гангрена] (1718-1724 КТ).

4. Джерело - місце і рік написання пам'ятки, ії скорочена назва, сторінка.

4.1. Скорочення назв пам'яток, що входять до канону джерел Словника украӥнської мови XVI-першої половини XVII cm.

4.2. Скорочення назв пам'яток, що входять до канону джерел Icmoричного словника украӥнського язиказа ред. Свгена Тимченка.

4.3. Скорочення назв опублікованих пам'яток подано за скороченням автора Комбінаторного словника української мови XVI-XVIII століть.

4.4. Невідоме чи невстановлене джерело позначене значком [?].

5. Цитата-ілюстрація наведена у Комбінаторному словнику української мови XVI-XVIII століть у таких випадках:

5.1. Затемнене значення реєстрового слова.

5.2. Потреба підтвердити:

a) образне значення реєстрового слова;

б) образність АСС у тексті (Батковъ хльбъ не навчить - XVIII ст. КТ) ${ }^{18}$;

в) оказіональність АСС у тексті (Метрики небесныли: въ Метрики небесныли тыли тылко льта нашь и дни въписаны бывають, въ которыи добродътель яковую сотворихмо, и шсвђдчили любовъ противко Богу и ближнему нашому - Київ, 1646 КТ)

5.3. Наявність цитат біля кожного АСС значно збільшила б обсяг створюваного паперового Комбінаторного словника української мови XVI-XVIII століть. Проте це цілком можливо і необхідно зробити в його електронній версії.

6. Деякі стрижневі субстантиви мають нижні індекси - цифра відповідає значенню, реалізованому в конкретному АСС. Наприклад:

аєрный (аирный) повітряний

- воздухи

- облако аирноє (Чернігів, 1646 КСУМ $^{16-17}$ ).

У цьому випадку користувачеві допоможе Словник малозрозумілих іменників, доданий до паперового варіанта Комбінаторного словника української мови XVI-XVIII століть. Реєстр такого глосарію містить багатозначне слово воздухъ: 1) ‘повітря’ і 2) ‘воздух, покров, накриття для євхаристійної чаші'. Проте основне призначення Словника малозрозумілих іменників, як свідчить його назва, - подати тлумачення тих назв реалій, об'єктів, явищ, станів, які не закріпилися в загальновживаному українському лексиконі: индит 'індитія, накриття на престолі', крутофиля 'розвага', рота 'присяга', оболоко 'хмара', святости 'Тайни Христові',

18 Картотека Історичного словника украӥнського язика. 
термина 'повідомлення', украса 'прикраса', хитрець 'творець, майстер, умілець', шарканє 'невдоволеність, нарікання', чтилище 'почитання, пошанування', юпа 'юпка, верхній чоловічий і жіночий одяг' та багато ін.

Таким чином, Комбінаторний словник української мови XVI-XVIII століть допомагає відтворити мовну картину світу українців того періоду. Із погляду лексикографії, пропонований словник оригінальний за ідеєю та формою, до того ж він продуктивно функціонуватиме і в традиційному „паперовому” форматі, і в електронній версії.

\section{СПИСОК СКОРОЧЕНЬ ДЖЕРЕЛ}

КомСУМ ${ }^{16-18}$ - Didik-Meuš Ganna. 2018. Kombinatornij slovnik ukraïnskoï movi XVI-XVIII stolit'. U: Didik-Meuš Ganna. 2018. Kombinatorika ukraïnskoï movi XVI-XVIII stolit': teorîa, praktika, slovnik. L'vìv: 503-687. [Дидик-Меуш Ганна. 2018. Комбінаторний словник украӥнської мови XVIXVIII століть. У: Дидик-Меуш Г. Комбінаторика української мови XVI-XVIII століть: теорія, практика, словник. Львів: 503-687].

КСУМ ${ }^{16-17}$ - Kartoteka Slovnika ukrä̈ns'koï movi XVI-peršö̈ polovini XVII st. U: Vìddil ukraïns'koï movi Ìnstitutu ukraïnoznavstva ìm. Ì. Krip âkeviča NAN Ukraïni, m. L'vìv. [Картотека Словника української мови XVI-першої половини XVII cm. У: Відділ української мови Інституту українознавства ім. I. Крип'якевича НАН України, м. Львів].

KT - Kartoteka İstoričnoho slovnika ukrä̈n'koho âzika za red. Êvhena Timčenka. U: Vìddil ukraïns'koï movi Ìnstitutu ukraïnoznavstva ìm. İ. Krip âkeviča NAN Ukraïni, m. L'vìv. [Картотека Історичного словника украӥнського язика за ред. Є. Тимченка. У: Відділ української мови Інституту українознавства ім. І. Крип'якевича НАН України, м. Львів].

СлДж ${ }^{16-17}$ - Hrinčišin Dmitro, Čikalo Mariâ. Red. 1994. Slovnik ukrä̈ns'koï movi XVI-peršö polovini XVII stolit'. Spisok vikoristanih. L'vìv. [Гринчишин Дмитро, Чікало Марія. Ред. 1994. Словник украӥнської мови XVI-першої половини XVII cm. Список використаних джерел. Львів].

CMI - Didik-Meuš Ganna. 2018. Slovnik malozrozumilih imennikiv. U: Didik-Meuš Ganna. 2018. Kombinatorika ukraïnskoï movi XVI-XVIII stolit': teoriâ, praktika, slovnik. L'vìv: 663-687. [Дидик-Меуш Ганна. 2018. Словник малозрозумілих іменників. У: Дидик-Меуш Г. Комбінаторика української мови 
XVI-XVIII століть: теорія, практика, словник. Львів: 663-687].

Тимч. - Timčenko Êvhen. Red. 1930-1932. İstoričnij slovnik ukraïns'koho âzika, t. 1 (A-Ž). Harkìv-Kiïv. [Тимченко Євген. Ред. 1930-1932. Історичний словник украӥнського язика, т. 1 ( $A-Ж)$. Харків-Київ].

\section{БІБЛІОГРАФІЯ}

Didik-Meuš Ganna. 2018. Kombìnatorika ukraïnskoï movi XVI-XVIII stolit': teoriâ, praktika, slovnik. L'vìv. [Дидик-Меуш Г. Комбінаторика украӥнської мови XVIХVIII ст.: теорія, практика, словник. Львів].

Gumec'ka Lukiâ. 1967. İstoričnij slovnik ukraïns'koï movi (deâkì aspekti teorï ì praktiki ukladannâ slovnika). „Movoznavstvo” nr 1: 44-49. [Гумецька Лукія. 1967. Icmoричний словник української мови (деякі аспекти теорії $і$ практики укладання словника). „Мовознавство”, № 1: 44-49].

Makovskij Mark. 2006. Lingvističeskaâ kombinatorika: opyt tipologičeskoj stratifikacii âzykovyh struktur. Moskva. [Маковский Марк. 2006. Лингвистическая комбинаторика: опыт типологической стратификаиии языковых структур. Москва].

Sorokin Urij. 1977. Čto takoe istoričeskij slovar'? W: Problemy istoričeskoj leksikografii. Leningrad: 4-27. [Сорокин Юрий. Что такое исторический словарь? В: Проблемь исторической лексикографии. Ленинград: 4-27].

Švedova Nataliâ. 1988. Paradoksy slovarnoj stat'i. W: Nacional'naâ specifika âzyka i ee otraženie v normativnom slovare. Moskva: 6-11. [Шведова Наталия. 1988. Парадоксы словарной статьи. В: Наџиональная специфика языка и ее отражение в нормативном словаре. Москва: 6-11].

Vlavackaâ Marina. 2011. Teoretičeskie problemy kombinatornoj lingvistiki. Leksikologiâ. Leksikografiâ. Novosibirsk. [Влавацкая Марина. 2011. Теоретические проблемы комбинаторной лингвистики. Лексикология. Лексикография. Новосибирск].

Vlavackaâ Marina. 2016. Kombinatornaâ lingvistika: aspekty izučeniâ sočetaěmosti slov. Novosibirsk. [Влавацкая Марина. 2016. Комбинаторная лингвистика: аспекты изучения сочетаемости слов. Новосибирск].

\section{UKRAINIAN HISTORICAL LEXICOGRAPHY, COMBINATION ISSUES AND A COMBINATORY DICTIONARY OF THE UKRAINIAN LANGUAGE}

Summary. The initial and practical interest in the compatibility of words as an object of lexicographic description led to the emergence of combinatorial lexicography - an independent direction within the general theory of lexicography. Part of the problem of describing compatibility is related to general lexicographic principles, and partly on the theory of compatibility. That is why combinatorial lexicography can be classified as a sphere of lexicography, the purpose of which is theoretical and practical issues of creating compatibility dictionaries.

Adjective-substantive phrases provide valuable material for lexicographical interpretation, as evidenced by the Combinatorial Dictionary of the Ukrainian Language of the 
16th-18th centuries - the first attempt in Slavic lexicography in general and in Ukrainian lexicography in particular to codify lexical-syntactic compatibility on the material of written monuments. Combinatorial dictionary of the Ukrainian language of the 16th-18th centuries combines the features of two lexicons. First, the combinatorial dictionary is a historical dictionary and, secondly, a combinatorial dictionary, that is, a compatibility dictionary. On the one hand, it occupies its proper place in the combinatorial lexicography system, on the other hand, it is a distinctive dictionary, since all of the combinatorial dictionaries known today are created with a didactic purpose, moreover, based on modern literary lexical material and function as bilingual.

Key words: combinability, combinatorics, combinatorial lexicography, historical dictionary, combinatorial dictionary, adjective-substantive phrases

\section{UKRAIŃSKA LEKSYKOGRAFIA HISTORYCZNA, PROBLEMATYKA ŁĄCZLIWOŚCI I SŁOWNIK KOMBINATORYCZNY JĘZYKA UKRAIŃSKIEGO}

Streszczenie. W artykule przedstawiono charakterystykę słownika kombinatorycznego według zasad praktycznej leksykografii kombinatorycznej oraz na tle leksykografii historycznej. Podano podstawowe zasady budowy powstającego Stownika kombinatorycznego języka ukraińskiego XVI-XVIII wieku na podstawie przymiotnikowo-rzeczownikowych związków syntaktycznych, a także cechy jego budowy, specyfikę bazy źródłowej oraz strukturę artykułu słownikowego. Wspomniano również o znaczeniu krótkiego Stownika rzeczowników niejasnych załączonego do Stownika kombinatorycznego języka ukraińskiego XVI-XVIII wieku.

Słowa klucze: łączliwość, kombinatoryka, leksykografia historyczna, leksykografia kombinatoryczna, słownik historyczny, słownik kombinatoryczny, przymiotnikowo-rzeczownikowy związek syntaktyczny 